\title{
PRAKTIK PENGANGGARAN PARTISIPATIF DALAM PEMANFAATAN DANA DESA DI KECAMATAN BRATI KABUPATEN GROBOGAN
}

\author{
PARTICIPATORY BUDGETING PRACTICES IN THE UTILIZATION OF VILLAGE \\ FUNDS IN BRATI SUB-DISTRICT GROBOGAN
}

\author{
Wildansyah Firdaus Adiguna $^{1)}$ \& Novia Arismawati ${ }^{2)}$ \\ ${ }^{1)}$ Magister Perencanaan Wilayah dan Kota Universitas Diponegoro \\ Email: wildansyahfirdausadiguna@gmail.com \\ ${ }^{2)}$ Kementerian Agraria dan Tata Ruang/Badan Pertanahan Nasional \\ Email: arismawati.novia@gmail.com \\ Diterima: 24 Januari 2020, Direvisi: 2 April 2020, Disetujui: 20 Mei 2020
}

\begin{abstract}
ABSTRAK
Pembangunan nasional merupakan upaya pemerintah untuk mewujudkan kesejahteraan masyarakat. Pembangunan nasional dilakukan dari unit terkecil yaitu pembangunan desa. Pemerintah menunjang dan mendorong percepatan pembangunan desa melalui Alokasi Dana Desa (ADD) dan Dana Desa. Dalam pembangunan nasional maupun desa diperlukan partisipasi aktif masyarakat. Salah satu bentuk pelibatan dan partisipasi masyarakat adalah dalam hal penganggaran kegiatan dan program prioritas desa. Tujuan penelitian ini untuk menjelaskan praktik partisipasi masyarakat di setiap tahapan penganggaran untuk pembangunan desa dalam rangka pemanfaatan dana desa di Kecamatan Brati Kabupaten Grobogan. Metode yang digunakan dalam penelitian ini yaitu metode kualitatif yang dilakukan dengan memberikan interpretasi terhadap data-data yang diperoleh. Adapun langkah-angkah yang dilakukan dalam analisis ini dengan reduksi data, penyajian data dengan bagan dan teks yang kemudian ditarik kesimpulan. Berdasarkan hasil analisis, disimpulkan bahwa praktik penganggaran partisipatif dalam pemanfaatan dana desa di Kecamatan Brati pelaksanaannya masih belum optimal melibatkan masyarakat, terutama pada tahap perencanaan anggaran.
\end{abstract}

Kata-kata kunci: penganggaran partisipatif, dana desa, Kecamatan Brati

\section{ABSTRACT}

National development is the government effort in achieving prosperity for the community who live in a city or a village. National development done from the smallest unit is developing village. The government stimulates rural development by Village Funds Allocation (ADD) and Village Funds. In this development context, community participation is needed. An example of the community involvement is giving some relevant suggestion related to budgeting and programming. The aim of this research is to explain the practices of community participation at each stage of budgeting for village development. The villages in the Sub District of Brati, the Regency of Grobogan is the research taken place. The method used in this study is a qualitative method performed by providing interpretation of the data obtained. The steps undertaken in this analysis starting with data reduction, data presentation with charts and text and then drawn some conclusions. Based on the results of the analysis, it can be concluded that the practice of participatory budgeting in the using of village funds in Brati Sub District was still less than the maximum by involving the community, especially at the budgeting stage.

Keywords: participatory budgeting, village funds, Brati Sub District 


\section{PENDAHULUAN}

Pembangunan nasional merupakan upaya pemerintah untuk mewujudkan kesejahteraan masyarakat. Pembangunan nasional diupayakan dengan berbagai kebijakan pemerintah salah satunya adalah otonomi daerah. Otonomi daerah merupakan kebijakan pemerintah pusat kepada pemerintah daerah dalam bentuk kewenangan mengatur daerah berdasarkan potensi dan masalah yang ada di daerah tersebut. Kebijakan ini dimaksudkan agar terwujud pembangunan nasional yang lebih merata antar daerah sesuai dengan keunikan masing-masing daerah.

Pembangunan nasional dilakukan dari unit terkecil yaitu pembangunan desa. Desa merupakan bagian terdepan dari upaya pembangunan yang berasal dari inisiatif masyarakat untuk mencapat tujuan kesejahteraan dan kemakmuran, juga keadilan memperoleh manfaat dan berkesinambungan (Purnamasari dan Ramdani, 2018). Pembangunan desa merupakan upaya yang dilakukan baik oleh pemerintah maupun masyarakat untuk meningkatkan kualitas hidup masyarakat perdesaan (Sutoro, E. et al., 2014). Undang-undang Nomor 6 Tahun 2014 tentang Desa menjelaskan bahwa untuk mendukung berjalannya pembangunan desa dilakukan melalui pemberian ruang masyarakat untuk berpartisipasi aktif dan secara berkelanjutan melakukan pemberdayaan kepada masyarakat desa. Pemerintah menunjang dan mendorong percepatan pembangunan desa melalui Alokasi Dana Desa (ADD) dan Dana Desa. Alokasi Dana Desa (ADD) merupakan stimulan dana yang dikelola oleh Kementerian Dalam Negeri yang dimanfaatkan untuk belanja aparatur, operasional pemerintahan desa, administrasi desa dan perawatan aset desa. Sedangkan, dana desa adalah dana yang bersumber dari APBN yang diperuntukkan bagi desa yang ditransfer melalui APBD kabupaten/kota dan digunakan untuk membiayai penyelenggaraan pemerintahan, pelaksanaan pembangunan, pembinaan kemasyarakatan, dan pemberdayaan masyarakat. Pemerintah memiliki kewajiban untuk meningkatkan taraf hidup masyarakat dengan mengeluarkan dan melaksanakan kebijakan peningkatan kesejahteraan masyarakat (Matridi et al., 2015). Dalam pelaksanaannya, penyelenggaraannya harus diperhatikan pada saat perencanaan, pengorganisasian, pelaksanaan dan pengawasan dalam rangka keberlanjutan kegiatan (Suharyadi dan Insani, 2016). Secara umum, Dana Desa merupakan dana yang diberikan kepada desa untuk pembangunan fisik desa serta pemberdayaan masyarakat desa untuk kesejahteraan masyarakat desa.

Secara spesifik, pengelolaan keuangan desa telah diatur dengan diterbitkannya Peraturan Menteri Dalam Negeri (Permendagri) Nomor 37 Tahun 2007 tentang Pedoman Umum Tata Cara Pelaporan dan Pertanggungjawaban Penyelenggaraan Pemerintahan Desa. Dalam peraturan tersebut dijelaskan bahwa, keuangan desa adalah semua hak dan kewajiban dalam rangka penyelenggaraan pemerintahan desa yang dapat dinilai dengan uang termasuk didalamnya segala bentuk kekayaan yang behubungan dengan hak dan kewajiban desa tersebut. Sumber keuangan desa pada umunya berasal dari Pendapatan Asli Desa (PAD), dana dari Pemerintah, dan hasil dari BUMDes. Adapun pelaksanaan urusan pemerintah daerah oleh pemerintah desa akan didanai dari APBD, sedangkan pelaksanaan urusan pemerintah pusat yang diselenggarakan oleh pemerintah desa didanai oleh APBN. 
Menurut Kementerian Desa, Pembangunan Daerah Tertinggal dan Transmigrasi (2016), bidang pembangunan desa ini berguna untuk meningkatkan kesejahteraan masyarakat desa dan kualitas hidup manusia serta penanggulangan kemiskinan. Prioritas penggunaan Dana Desa diarahkan untuk pelaksanaan program dan kegiatan pembangunan desa. Selain untuk membiayai pembangunan fisik desa, Dana Desa juga digunakan untuk membiayai kegiatan dan program bidang pemberdayaan masyarakat desa. Kegiatan dan program pemberdayaan masyarakat ini bertujuan untuk meningkatkan kapasitas masyarakat desa dalam pengembangan wirausaha, peningkatan pendapatan, serta perluasan skala ekonomi individu atau kelompok masyarakat dan desa.

Dalam pemanfaatan Dana Desa untuk pembangunan infrastruktur desa selain harus dilakukan sesuai dengan ketentuan, pembangunan infrastruktur yang dilakukan harus mampu menerapkan prinsip pembangunan desa, agar pembangunan dapat dinikmati dan dimanfaatkan masyarakat desa dengan baik. Haeruman dalam Wahidi (2015) menjelaskan bahwa pembangunan perdesaan adalah sebuah proses natural yang berporos pada potensi yang dimiliki oleh masyarakat perdesaan itu sendiri. Pendekatan ini meminimalkan adanya campur tangan pihak luar dalam mengintervensi setiap program pembangunan yang berlaku di daerah tersebut. Menurut Hanifah dan Praptoyo (2015), dalam melaksanakan pemerintahan di desa, pemerintah desa wajib mengelola keuangan desa secara transparan, akuntabel dan partisipatif. Transparan diartikan dengan mengelola secara terbuka, akuntabel berarti dipertanggungjawabkan secara hokum, dan partisipatif bermakna melibatkan masyarakat dalam prosesnya.
Partisipasi masyarakat diperlukan dalam pembangunan nasional maupun desa. Partisipasi masyarakat akan meningkatkan tata kelola kawasan dan mendorong keterbukaan sosial dan transparansi (Daniel, 2014). Kerjasama yang baik antara masyarakat dengan pemerintah desa dapat mewujudkan tatakelola yang baik. Tata kelola kelembagaan di tingkat desa memiliki keterkaitan erat antara politik, ekonomi dan kemasyarakatan yang mampu mendorong pembangunan perdesaan selain dari kelembagaan desa juga dalam pemanfaatan sumber daya alam (Bebbington et al., 2006). Pemerintah desa memiliki andil dalam mengatur pembangunan infrastruktur dengan memanfaatkan dana desa. Adanya pemerintah lokal yang baik menjadi kunci memotivasi orang yang terkait dan juga perlu dukungan dari pemerintah lokal untuk memberikan sokongan pendanaan juga. (Chong et al., 2016). Partisipasi aktif masyarakat diperlukan mulai dari perencanaan, pengaturan, implementasi, dan pengawasan kegiatan.

Pendekatan pembangunan yang menekankan keikutsertaan masyarakat berupa kegiatan pemberdayaan menjadi sebuah usaha untuk meningkatkan manfaat dari pembangunan tersebut, agar dapat memenuhi kebutuhan masyarakat melalui asas-asas partisipasi dan keadilan oleh masyarakat (Mardikanto dan Soebiato, 2013). Sumodiningrat dalam Oleh (2014) menjelaskan bahwa pemberdayaan yang dilakukan dilaksanakan dengan tujuan masyarakat mampu mandiri hingga mampu dilepas agar memiliki inisiatif sendiri, sehingga kegiatan pemberdayaan tersebut tidak bersifat selamanya. Dilihat dari pendapat tersebut bahwa proses belajar dalam rangka pemberdayaan masyarakat akan berlangsung secara bertahap. 
Upaya untuk mewujudkan kesejahteraan masyarakat salah satunya adalah dengan adanya pelibatan masyarakat dalam proses penganggaran yang terdiri dari tahap perencanaan, pelaksanaan, hingga pengawasan program. Pelibatan masyarakat harus mampu mewadahi semua golongan, sehingga pengambilan keputusan terkait prioritas program dan prioritas anggaran merupakan hasil kesepakatan bersama dan manfaatnya dapat dirasakan oleh semua kalangan. Sehubungan dengan penganggaran pembangunan desa, menurut Waskitoaji, et al (2016) muncul tantangantantangan dalam pengelolaan dana desa yang melingkupi:

- Kualitas perencanaan pembangunan desa yang masih rendah,

- Tingginya ketergantungan desa terhadap supra desa,

- cara pandang dan keterbatasan pemahaman,

- kondisi geografis,

- struktur dan budaya masyarakat,

- minimnya pengarusutamaan gender di dalam penganggaran partisipatif, serta

- rendahnya komitmen dalam keterbukaan informasi dan akuntabilitas.

Salah satu bentuk pelibatan dan partisipasi masyarakat adalah dalam hal penganggaran kegiatan dan program prioritas desa. Perencanaan dan penganggaran partisipatif merupakan pendekatan yang memastikan adanya pelibatan aktif dari masyarakat dalam mengidentifikasi prioritas pembangunan, kebijakan dan kegiatan yang memerlukan alokasi anggaran maupun sumber daya (Dakelan, et al., 2016). Penganggaran partisipatif menurut Goldfrank dalam Grillos (2017) adalah sebuah proses pelibatan masyarakat untuk pengambilan keputusan atau berkontribusi menjadi bagian dari pengambilan keputusan anggaran publik melalui rangkaian pertemuan tahunan yang rutin dijalankan oleh pemerintah terkait. Dalam model ini, masyarakat memegang kendali atas keputusan dan hasil dari musyawarah yang dilaksanakan.

Pemanfaatan dana desa ini juga berlaku di Kecamatan Brati. Pembangunan fisik desa diarahkan pada pemberdayaan masyarakat melalui pembangunan infrastruktur desa. Kecamatan Brati terbagi menjadi 9 desa. Dalam pelaksanaannya, mucul beberapa masalah terkait pengelolaan Dana Desa. Beberapa permasalahan yang dihadapi oleh masingmasing desa antara lain:

- Belum baiknya tata kelola dana desa untuk pengembangan desa.

- Rendahnya partisipasi masyarakat untuk pembangunan desa, misalnya ketika Musrenbangdes dalam penyusunan RPJMDes, RKPDes dan APBDes yang diikuti oleh pemerintah desa bersama-sama dengan Tim Pelaksana Desa, lembaga kemasyarakatan desa dan masyarakat.

- Masyarakat kurang dilibatkan dalam proses penyusunan rencana pembangunan dan rencana penganggaran. Kurangnya pelibatan masyarakat dalam perencanaan menyebabkan rawannya manipulasi. Hal ini berdampak APBDesa yang disusun tidak sepenuhnya menggambarkan kebutuhan yang diperlukan desa.

- Musyawarah hanya dilakukan sebagai formalitas, sehingga rawan terjadi tindakan manipulatif terhadap hasil musyawarah.

- Terjadi inkonsistensi antara RKPDes dengan APBDes.

- Terlalu berorientasi pada pembangunan fisik, sehingga kurang memperhatikan kebutuhan untuk pemberdayaan masyarakat miskin dan perempuan. 
- Kurangnya keterwakilan perempuan dan kelompok miskin.

Adanya partisipasi aktif dari masyarakat dapat meningkatkan efektifitas musyawarah, dimana masyarakat dapat memberikan masukan dan usulan dalam pengambilan kebijakan. Selain itu, masyarakat dapat melakukan intervensi pengambilan kebijakan, agar kebijakan yang diimplementasikan dapat tepat guna di masyarakat. Setelah itu, dilakukan perbandingan terhadap intensitas partisipasi masyarakat serta upaya pengajuan dana desa dan pengelolaan dana desa di masing-masing desa di Kecamatan Brati. Hal inilah yang menjadi rumusan masalah dalam penelitian ini yaitu: "Bagaimana praktik penganggaran partisipatif oleh masyarakat dalam pemanfaatan Dana Desa di Kecamatan Brati?"

Tujuan penelitian ini untuk menjelaskan praktik partisipasi masyarakat di setiap tahapan penganggaran untuk pembangunan desa dalam rangka pemanfaatan Dana Desa di Kecamatan Brati Kabupaten Grobogan. Ruang lingkup wilayah dari penelitian ini yaitu Kecamatan Brati Kabupaten Grobogan yang melingkupi 9 desa, yaitu Kronggen, Katekan, Tegalsumur, Karangsari, Tirem, Temon, Lemahputih, Jangkungharjo, dan Menduran. Kecamatan Brati terletak di sebelah utara Kecamatan Purwodadi yang menjadi ibu kota Kabupaten Grobogan.

\section{METODE}

Metode kualitatif dilakukan dengan memberikan interpretasi dari data-data yang diperoleh. Adapun langkah-angkah yang dilakukan dalam analisis ini dengan reduksi data, penyajian data dengan bagan dan teks yang kemudian ditarik kesimpulan. Penelitian ini menafsirkan dan menuturkan data yang sesuai dengan realita yang terjadi, dari sisi kelembagaan baik pemerintah desa, Lembaga Pemberdayaan Masyarakat Desa (LPMD) maupun Badan Perwakilan Desa (BPD) dan juga partisipasi dari masyarakat desa. Proses pengumpulan data dalam penelitian ini diperoleh dengan melakukan survei lapangan, melalui observasi serta melalui teknik wawancara dan kuesioner. Wawancara ditujukan kepada pihak pemerintah desa, sedangkan kuesioner menyasar responden masyarakat di seluruh desa di Kecamatan Brati. Metode pengumpulan data ini dilakukan dengan menyelidiki, mengamati serta mengumpulkan data, informasi maupun fenomena yang terjadi di lokasi penelitian.

\section{HASIL}

\section{Gambaran Umum Wilayah}

Kecamatan Brati merupakan salah satu kecamatan di Kabupaten Grobogan Provinsi Jawa Tengah. Kecamatan ini memiliki luas \pm 5.489,6 Ha. Secara administratif, Kecamatan Brati terdiri dari 9 desa, yaitu Kronggen, Katekan, Tegalsumur, Karangsari, Tirem, Temon, Lemahputih, Jangkungharjo, dan Menduran. Kecamatan Brati berbatasan langsung dengan Kecamatan Grobogan, Kecamatan Purwodadi, Kecamatan Penawangan, dan Kecamatan Klambu. Pusat kecamatan ini berada di Desa Kronggen berjarak sekitar $12 \mathrm{Km}$ dari ibukota Kabupaten Grobogan.

Perekonomian di Kecamatan Brati ditopang dari sektor primer yakni pertanian. Berdasarkan data BPS tahun 2018, mayoritas komoditas pertanian yang di produksi adalah padi, jagung, kacang hijau, dan kedelai. Pada tahun 2018, luas total lahan sawah di Kecamatan Brati adalah $2.404,4 \mathrm{Ha}$ atau 43,8 persen dari total luas Kecamatan Brati. Dengan ditopang oleh sektor pertanian, mayoritas penduduk bermata pencaharian dari sektor pertanian. Separuh lebih penduduk Kecamatan Brati menggantungkan hidupnya dari sektor pertanian tanaman pangan. Selain itu, banyaknya warung, 
toko dan kios menjadi sarana lapangan usaha masyarakat. Pembagian wilayah administratif desa dan juga luas wilayah dapat dilihat pada Gambar 1 berikut:

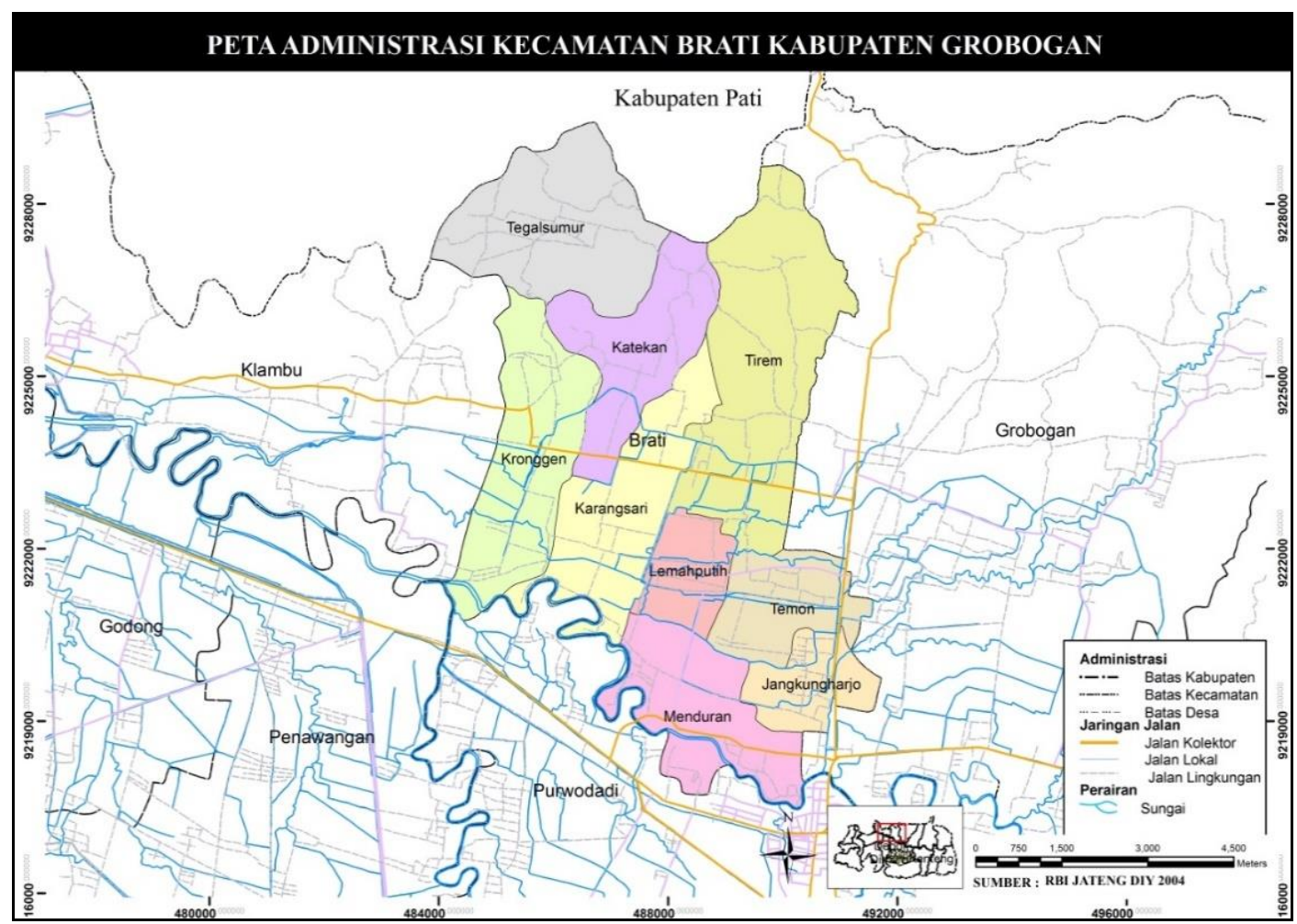

Gambar 1: Peta Wilayah Kecamatan Brati Kabupaten Grobogan

Sumber: Diolah dari Data Peta RTRW Kabupaten Grobogan Tahun 2010-2030

\section{Praktik Penganggaran Partisipatif dalam Pemanfaatan Dana Desa}

Sebelum dilaksanakan Musyawarah Perencanaan Pengembangan Desa (Musrenbangdes), terdapat beberapa tahapan yang dilaksanakan baik oleh masyarakat maupun aparatur desa. Pelaksanaan pra Musrenbangdes ini menjadi bahan acuan dalam pelaksanaan Musrenbangdes. Musyawarah juga dilakukan di tingkat Rukun Tetangga (RT), namun pelaksanaan ini dilakukan bukan dalam forum resmi yang dilaksanakan dengan pembahasan yang khusus untuk membahas pembangunan desa, melainkan dilakukan bersama dengan acara-acara keagamaan rutin tiap minggu, seperti yasinan. Musyawarah ini dilaksanakan sebelum Musrenbangdes, antara bulan Januari hingga Juni. Hasil dari jaring pendapat ini kemudian dibawa ke forum Musyawarah Dusun (Musdus).

Hasil musyawarah dusun menjadi acuan dalam Musrenbangdes, masyarakat memberikan usulan secara tertulis tidak dilakukan secara lisan. Semua usulan dari masyarakat ditampung oleh desa untuk direkapitulasi dan ditentukan prioritas program pembangunan. Dalam Musrenbangdes, partisipasi masyarakat dalam pengambilan kebijakan terbatas pada pengusulan program. Pelaksanaan Musrenbangdes dilaksanakan pada Bulan Juli. Setelah itu dilakukan pelaporan kepada kecamatan untuk dilakukan verifikasi pada bulan Agustus. Tahapan pelaksanaan dari musyawarah tingkat dusun hinggan musyawarah di tingkat 
desa dilaksanakan di seluruh desa. Variasi pelaksanaan terjadi di forum musyawarah tingkat dusun, yang disesuaikan dengan kondisi dan budaya di dusun masingmasing. Pelaksanaan Musrenbangdes dapat dilihat pada Gambar 2 berikut:

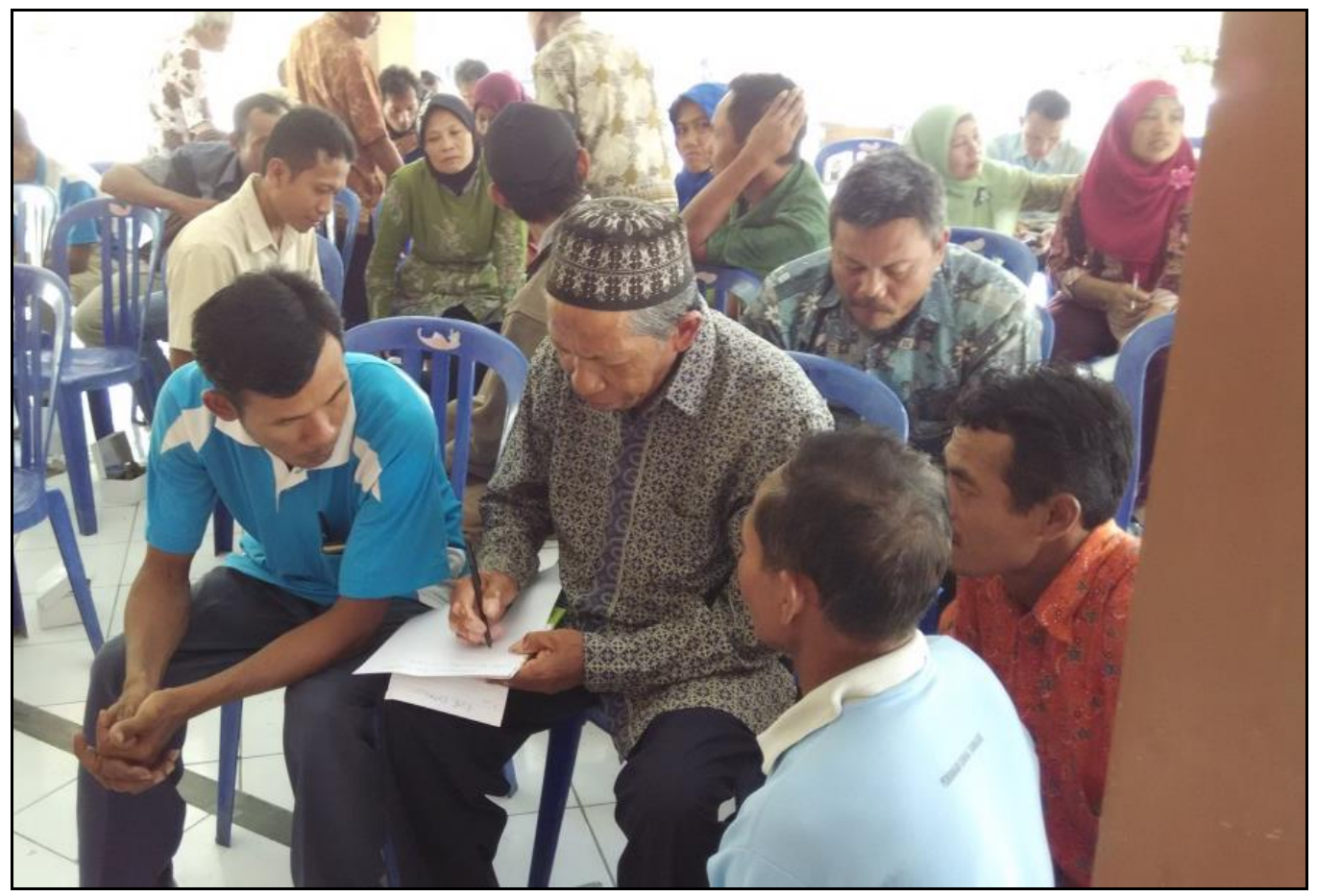

Gambar 2: Kegiatan Pengusulan Program oleh Masing-masing Dusun

Sumber: Hasil Observasi

Hasil dari Musrenbangdes menjadi acuan penyusunan Rencana Kerja Pemerintah Desa (RKPDes). Penyusun RKPDes merupakan tim yang dibentuk oleh kepala desa yang terdiri dari 7 hingga 11 orang. Pelibatan masyarakat dalam penyusunan RKPDes ini tidak ada, sehingga semua dilaksanakan oleh kepala desa, aparatur desa, tim penyusun dan Badan Perwakilan Desa (BPD). Penyusunan RKPDes dilaksanakan bulan September.

Penyusunan Rancangan Angga-ran Pendapatan dan Belanja Desa (RAPBDes) didahului dengan musyawa-rah anggaran yang dilaksanakan oleh tim penyusun, aparatur desa dengan BPD. Penganggaran sebenarnya sudah dapat dilaksanakan pada tahap Musrenbangdes, ketika masyarakat memberikan usulan program. Di beberapa desa seperti Katekan dan Temon, masyarakat memberikan usulan Rencana Anggaran Biaya (RAB) untuk pembangunan infrastruktur. Namun, besar biaya yang diusulkan dihitung berdasarkan perkiraan dan tidak berdasarkan hitungan yang tepat sesuai dengan volume pekerjaan. Hal ini menyebabkan usulan di masyarakat lebih bersifat placation, dimana saran/usulan dari masyarakat ditampung namun tidak selamanya usulan tersebut diterima. Pada kasus lain, karena perhitungan anggaran hanya berdasarkan perkiraan, masyarakat lebih ditempatkan pada fungsi consultation, dimana usulan yang ditampung tidak menjadi pertimbangan dalam pengambilan keputusan. Sebab, perhitungan RAB akan dilaksanakan pada penyusunan RKPDes dengan perhitungan volume fisik bangunan. 
Pelibatan masyarakat pada tahap ini hanya terjadi di Desa Karangsari dan Tegalsumur, itupun hanya perwakilan masyarakat. Pada musyawarah ini masyarakat tidak dilibatkan dengan pertimbangan penghematan anggaran serta menghindari konflik antar dusun karena hasil keputusan. Setelah RAPBDes selesai, selanjutnya dilaksanakan pengesahan RAPBDes menjadi Anggaran Pendapatan dan Belanja Desa (APBDes) oleh kepala desa dengan BPD. Pihak yang terkait dengan penyusunan APBDes seperti dalam bagan pada Bagan 1 berikut:

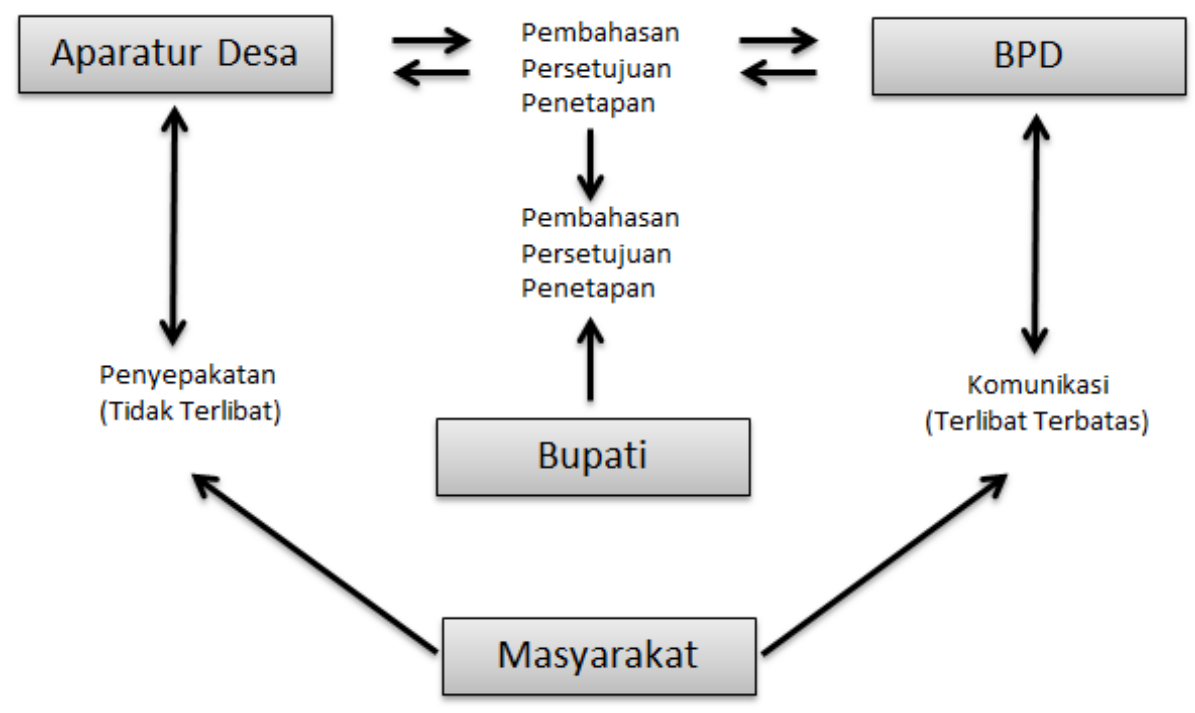

Bagan 1: Pihak yang Terkait dalam Penganggaran Desa di Kecamatan Brati Sumber: Hasil Analisis

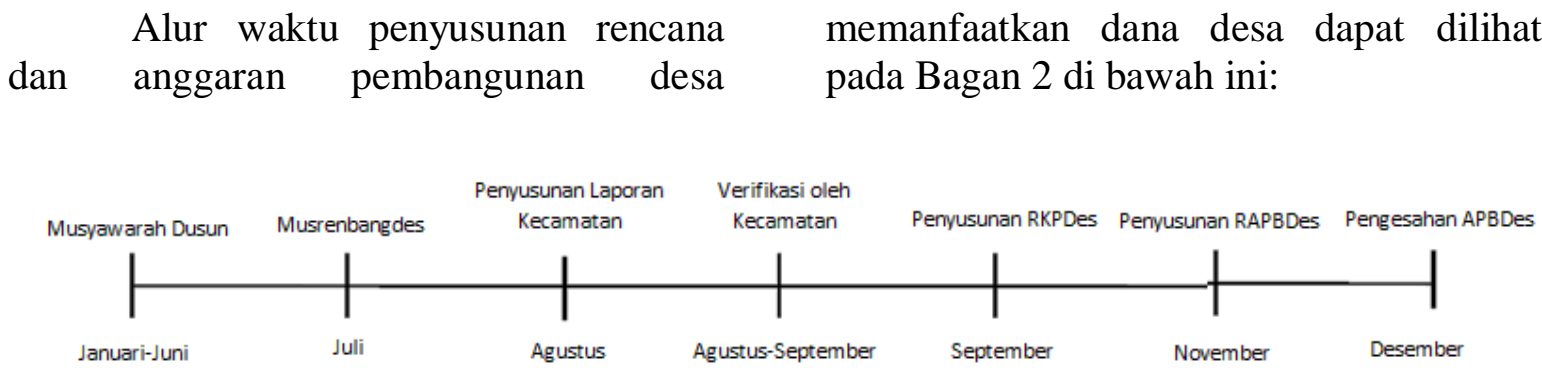

Bagan 2: Alur Waktu Penyusunan Perencanaan dan Penganggaran Desa Sumber: Hasil Analisis

Sedangkan proses pelaksanaan perencanaan dari Musyawarah Dusun (Musdus) hingga pengesahan APBDes menjadi Perdes beserta tingkat partisipasi masyarakat dapat dilihat pada bagan Bagan 3 berikut: 


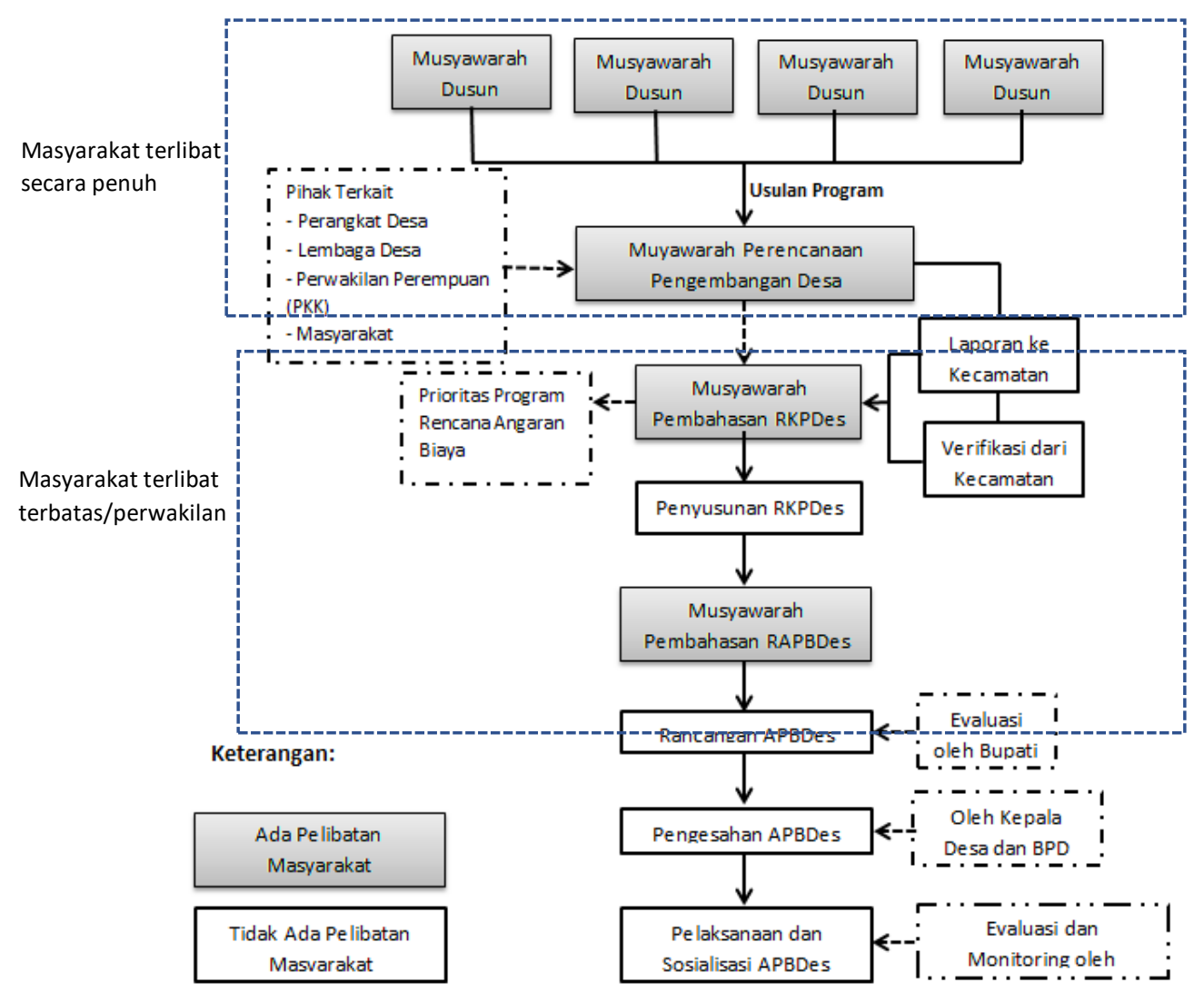

Bagan 3: Bagan Pelaksanaan Penganggaran Partisipatif di Kecamatan Brati Sumber: Hasil Analisis

\section{PEMBAHASAN}

Kegiatan penganggaran partisipatif di Kecamatan Brati diawali dengan kegiatan Musyawarah Dusun (Musdus), Musyawarah Perencanaan Pembangunan Desa (Musrenbangdes), penyusunan RKPDes, penyusunan RAPBDes dan pengesahan APBDes. Pada tahap kegiatan Musdus dan Musrenbangdes, masyarakat dilibatkan secara mutlak. Sedangkan dalam penyusunan RKPDes dan penyusunan RAPBDes, hanya terdapat 2 desa, yaitu Desa Karangsari dan Desa Tegalsari.

Proses penganggaran partisipatif di Kecamatan Brati dapat dibedakan menjadi 2 tipe, yaitu tipe perwakilan BPD dan tipe pelibatan masyarakat di dalam tahapan pembahasan RAPBDes. Adapun penjelasannya sebagai berikut:

- Tipe perwakilan BPD

Tipe ini dalam pelaksanaannya hanya melibatkan perangkat desa dan BPD sebagai wakil dari masyarakat. pada musyawarah ini masyarakat tidak dilibatkan dengan pertimbangan penghematan anggaran serta menghindari konflik antar dusun karena hasil keputusan. Fungsi BPD menjadi penyalur antara masyarakat desa dengan setiap proses yang berjalan di desa, sehingga BPD merupakan perwakilan masyarakat di dalam musyawarah Anggota BPD sebagai wakil masyarakat desa diharapkan dapat menjadi "jembatan" antara proses-proses yang terjadi di 
tingkat desa dengan kepentingan warga. Praktik ini dilaksanakan di Desa Kronggen, Katekan, Tirem, Temon, Lemahputih, Jangkungharjo dan Menduran. Model penyusunan RAPBDes ini dapat dilihat pada Bagan 4 berikut.

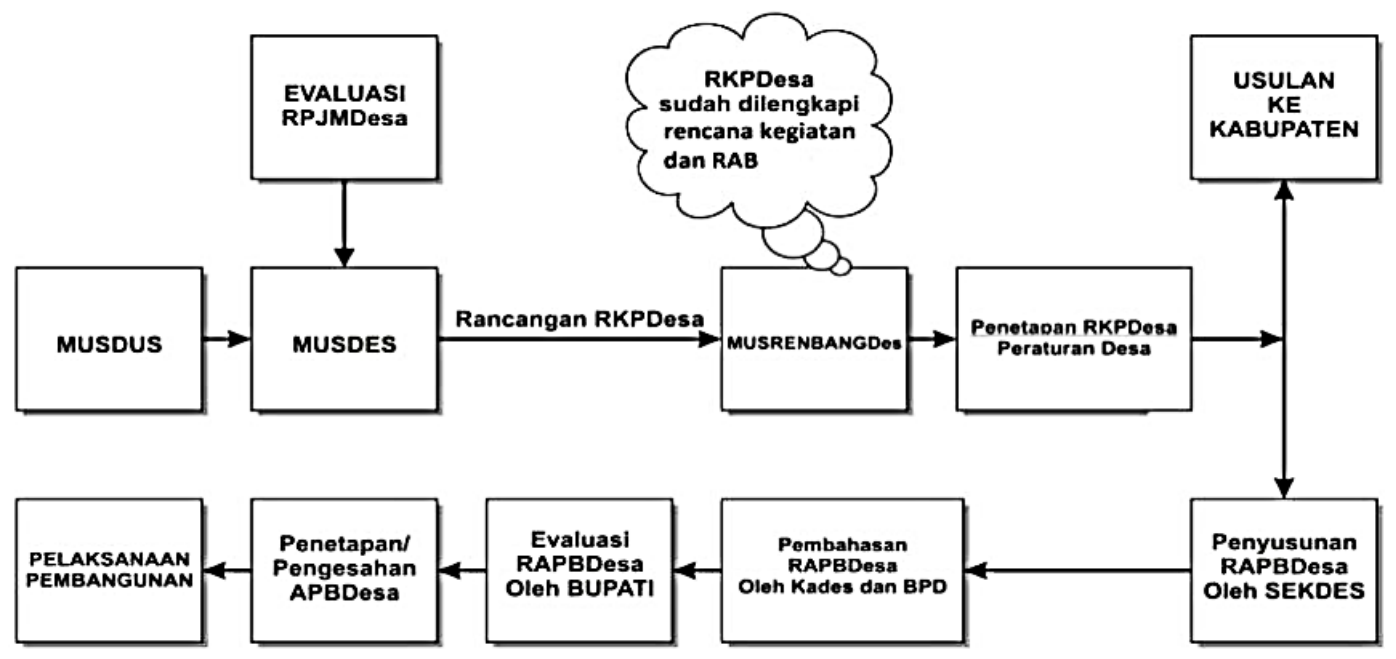

Bagan 4: Penganggaran Partisipatif dengan Perwakilan BPD

Sumber: Diadopsi dari Waskitoaji, et al, 2016

- Tipe pelibatan masyarakat di dalam tahapan pembahasan RAPBDes

Secara garis besar, model ini mempunyai kesamaan alur dan tahapan dengan model perwakilan BPD. Akan tetapi hal yang berbeda di sini adalah siapa yang hadir dan terlibat di dalam musyawarah pembahasan RAPBDes. Jika di dalam model perwakilan BPD, musyawarah pembahasan RAPBDes hanya dihadiri oleh pemerintah desa dan BPD dan tidak dibuka untuk umum. Pada model ini, musyawarah pembahasan RAPBDes dibuka bagi keterlibatan unsur masyarakat. Pada model ini, unsur masyarakat bersama dengan pemerintah desa dan BPD akan membahas RAPBDes yang telah disusun oleh Sekretaris Desa. Desa Tegalsumur dan Karangsari merupakan desa yang melibatkan masyarakat dilibatkan melalui perwakilan masyarakat. Model penyusunan RAPBDes ini dapat dilihat pada Bagan 5 berikut. 


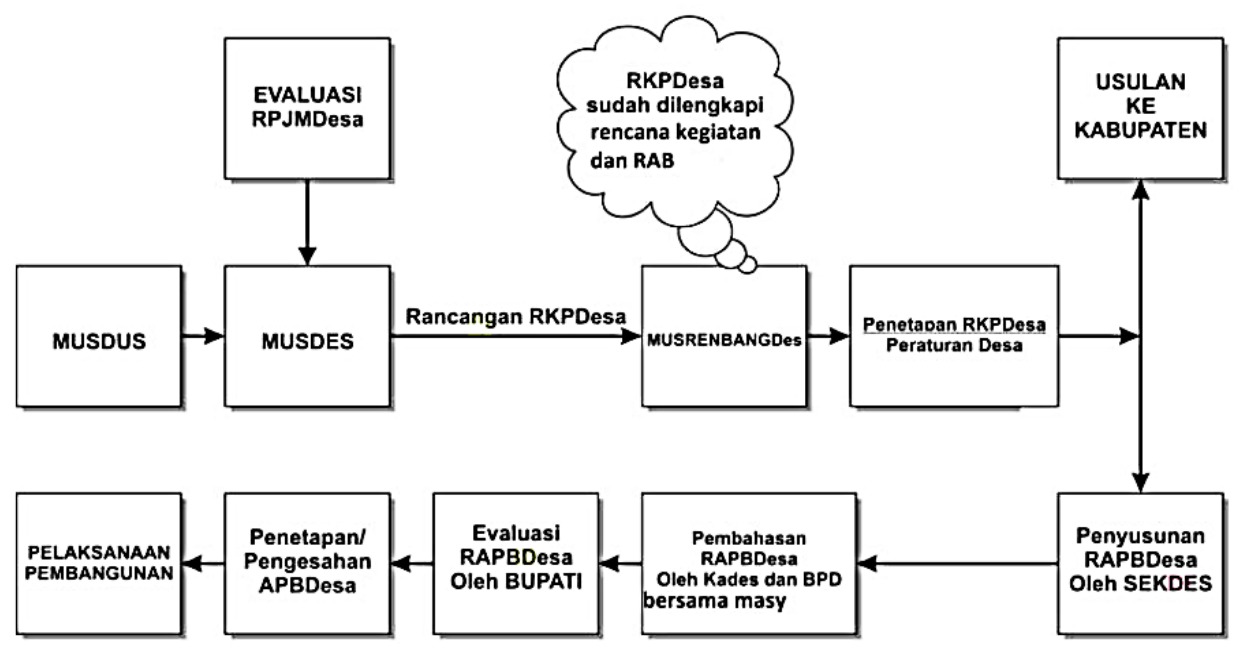

Bagan 5: Penganggaran Partisipatif dengan Pelibatan Masyarakat dalam Pembahasan Sumber: Diadopsi dari Waskitoaji, et al, 2016

Setelah RKPDes ditetapkan, maka dilanjutkan proses penyusunan APBDes. APBDes merupakan rencana anggaran tahunan pemerintah desa yang ditetapkan untuk menyelenggarakan program dan kegiatan yang menjadi kewenangan desa. Berdasarkan Permendagri Nomor 114 Tahun 2014 tentang Pedoman Pembangunan Desa, dalam perancangan anggaran, peran keterlibatan masyarakat seharusnya menjadi faktor penting dalam rangka: (1) Menumbuhkan rasa tanggung jawab masyarakat atas segala hal yang telah diputuskan dan dilaksanakan; (2) Menumbuhkan rasa memiliki, sehingga masyarakat sadar dan sanggup untuk memelihara dan mengembangkan hasil pembangunan; dan (3) Memberikan legitimasi atau keabsahan atas segala yang telah diputuskan.

Ketika APBDes telah disahkan, perlu adanya monitoring yang dilakukan oleh masyarakat. Masyarakat perlu mengakses informasi terkait rencana pelaksanaan kegiatan sekaligus penggunaan anggarannya. Untuk menjamin transparansi penggunaan dana dalam pemanfaatan dana desa ini dilakukan dengan pembuatan papan infografis. Infografis merupakan salah satu media yang dilakukan oleh pemerintah desa mengenai rencana penggunaan dana yang telah dirumuskan dari hasil usulan-usulan masyarakat pada Musrenbangdes yang telah dilaksanakan. Infografis ini menjelaskan mengenai pendapatan keuangan desa dan rencana penggunaan dana untuk belanja kegiatan pembangunan desa. Di Kecamatan Brati diwajibkan membuat infografis oleh pihak kecamatan, namun beberapa desa juga belum membuat infografis. Hingga sejauh ini, desa yang sudah membuat transparansi penggunaan dana APBDes baru 5 desa, dimana 4 desa membuat infografis, yaitu Desa Kronggen, Tirem, Menduran dan Katekan serta 1 desa yang membuat tabel penggunaan dana selama termin 1 , yaitu Desa Temon. Dengan adanya infografis ini, harapannya masyarakat dapat melakukan fungsi kendali dalam pemanfaatan dana desa. Infografis yang menjelaskan mengenai pendapatan desa dan besar dana yang dialokasikan untuk pembangunan diharapkan dapat memberikan transparansi dari pemerintah desa kepada masyarakat. Dokumentasi infografis di masing-masing desa dapat dilihat pada Gambar 2 berikut: 


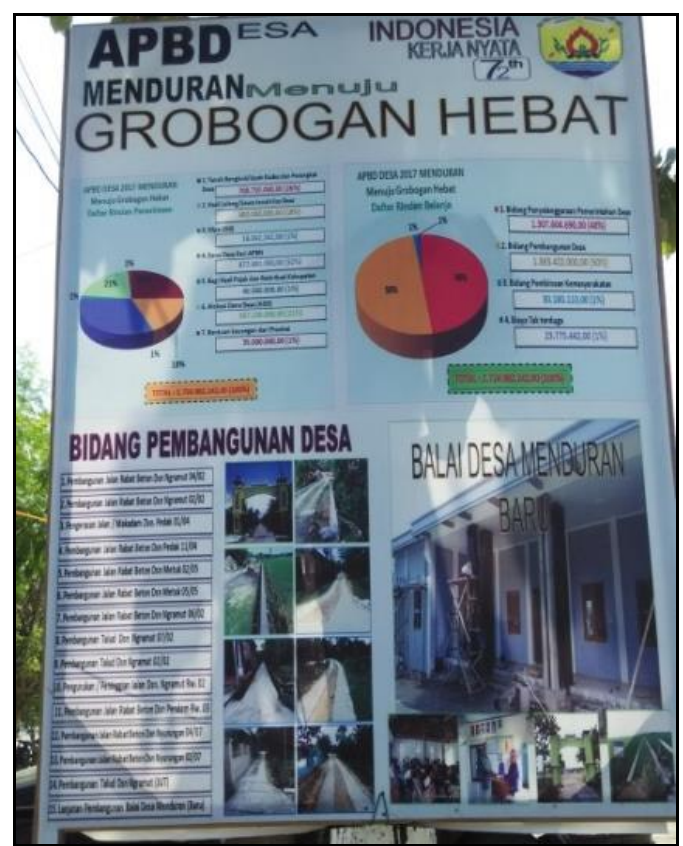

Gambar 2: Infografis APBDes di Desa Menduran Sumber: Hasil Observasi

Penatausahaan kelembagaan desa meliputi kegiatan penyusunan rencana anggaran desa, pelaksanaan pembangunan, pencatatan keuangan dan pelaporan keuangan desa. Selain dari jabatan kepala desa dan perangkat desa, dalam mewujudkan tata kelola kelembagaan desa yang baik dalam pengelolaan dana desa, terdapat beberapa lembaga desa yang dilibatkan dalam proses perencanaan, penganggaran dan implementasi dana desa. Berikut bagan pengorganisasian dalam pengelolaan perencanaan dan penganggaran dalam pemanfaatan dana desa pada Bagan 6 berikut:

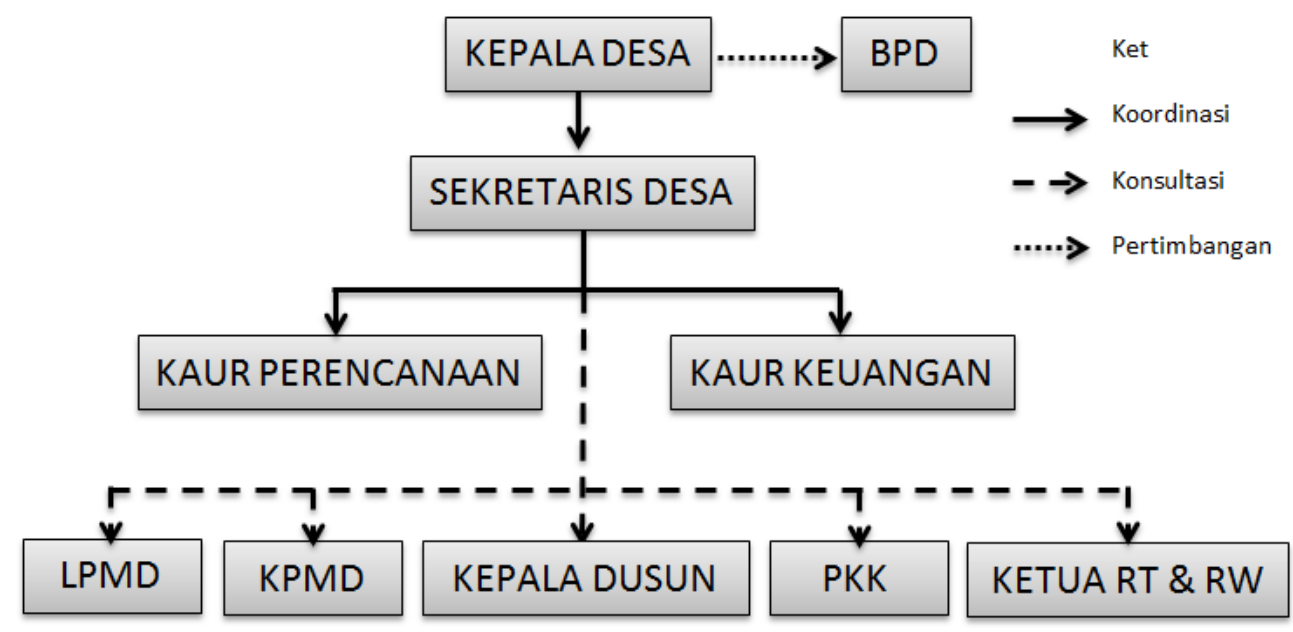

Bagan 6: Koordinasi Perencanaan dan Penganggaran dalam Pemanfaatan Dana Desa di Kecamatan Brati

Sumber: Hasil Analisis 
Pengembangan masyarakat dalam pelaksanaan dana desa secara fungsi dilaksanakan oleh LPMD dan KPMD. Namun karena kurang berjalannya tugas dua lembaga tersebut, kegiatan pemberdayaan dan penggerakan masyarakat langsung dikelola oleh desa. Fungsi masyarakat dalam pemanfaatan dana desa diantaranya memberikan masukan dan usulan pembangunan desa serta ikut serta dalam pelaksanaan pembangunan desa. Tim Pelaksana Kegiatan (TPK) merupakan unsur tim desa yang berfungsi untuk membantu Kepala Desa dalam pelaksanaan pengelolaan dana desa. TPK dibentuk oleh desa tanpa melibatkan masyarakat. Tim ini dipilih dari masyarakat yang dianggap mampu oleh desa untuk mengelola keuangan desa. Berdasarkan hasil kuesioner, masyarakat tidak mengetahui pembentukan TPK. Sehingga dalam pelaksanaan karena tidak melibatkan masyarakat, dikhawatirkan pembentukan tim ini dekat dengan unsur nepotisme karena tidak ada upaya kendali dari masyarakat. TPK memiliki pekerjaan mulai perencanaan volume bangunan hingga pelaksanaan pembangunan.

\section{SIMPULAN}

Penganggaran partisipatif dalam pemanfaatan dana desa di Kecamatan Brati dalam pelaksanaannya masih belum optimal. Hal ini dapat dari keterlibatan masyarakat pada masing-masing tahap dalam penganggaran partisipatif. Pelibatan masyarakat secara aktif terlaksana pada tahap Musdus dan Musrenbangdes. Namun, pada tahap penyusunan RKPDes dan RAPBDes, keterlibatan masyarakat terbatas. Dalam menyusun RKPDes dilaksanakan oleh pihak desa dengan didasarkan hasil Musrenbangdes, tahap ini tidak melibatkan masyarakat pada pengambilan keputusannya. Pada tahap penyusunan RAPBDes, hanya di Desa Tegalsumur dan Desa Karangsari, sedangkan di desa lainnya aspirasi masyarakat diwakilkan melalui BPD. Padahal, dalam Permendagri Nomor 114 Tahun 2014 menjelaskan pentingnya peran keterlibatan masyarakat dalam perencanaan pembangunan dan penganggaran. Wujud keterlibatan masyarakat dapat dilakukan dengan ikut serta bersama tim pengelola dalam menyusun rencana program dan anggaran dan aktif meminta dan mengakses informasi dan melakukan audit partisipatif. 


\section{DAFTAR PUSTAKA}

\section{Jurnal}

Bebbington, A., L. Dharmawan, E. Fahmi, dan S. Guggenheim. 2006. Local Capacity, Village Governance, and the Political Economy of Rural Development in Indonesia. World Development 34: 19581976.

doi.org/10.1016/j.worlddev.2005. 11.025

Chong, J., Abeysuriya, K., Hidayat, L., Sulistio, H., \& Willetts, J. 2016. Strengthening Local Governance Arrangements for Sanitation: Case Studies of Small Cities in Indonesia. Aquatic Procedia, 6, 64-73. doi.org/10.1016/j.aqpro. 2016.06.008

Daniel, M. M. 2014. Local and Community Driven Development approach in the provision of basic facilities in Jos, Nigeria. Cities 39: 99-108. doi.org/10.1016/ j.cities.2014.03.003

Grillos, T. 2017. Participatory Budgeting and the Poor: Tracing Bias in a Multi-Staged Process in Solo, Indonesia. World Development, xx. doi.org/10.1016/j.worlddev. 2017.03.019

Hanifah, Suci Indah \& Praptoyo, S. 2015. Akuntabilitas dan Transparansi Pertanggungjawaban Anggaran Pendapatan Belanja Desa (APBDes). Jurnal Ilmu \& Riset Akuntansi, 4(8)

Matridi, R. A., Zuraidi, D., Setyadiharja, R., Sanopaka, E., Effendi, D., \& Utari, D. S. 2015. An Evaluation of P3DK (An Acceleration of Development Village Program): A Reviewing on Failure toward Revolving Loan Fund System in Kepulauan Riau Province, Indonesia. Procedia - Social and Behavioral Sciences, 169(August
2014), 189-197. http://doi.org/ 10.1016/j.sbspro.2015.01.302

Suharyadi, Heri \& Insani, Aji. 2016. Manajemen Pemerintahan Dalam Program Unit Reaksi Cepat Tambal Jalan Di Kota Bandung Tahun 2015. Cosmogov: Jurnal Ilmu Pemerintahan, 2(2)

Purnamasari, Hanny \& Ramdani, Rachmat. 2018. Manajemen Pemerintahan dalam Pembangunan Desa di Desa Lemahabang Kecamatan Lemahabang Kabupaten Karawang. Cosmogov: Jurnal Ilmu Pemerintahan, 4(2), 160-172

Oleh, H. F. 2014. Pelaksanaan Kebijakan Alokasi Dana Desa ( ADD ) dalam Memberdayakan Masyarakat Desa Cerme, Kecamatan Grogol, Kabupaten Kediri. Jurnal Kebijakan Dan Manajemen Publik Universitas Airlangga, 2(1), 1-8

Buku

Badan Pusat Statistik Kabupaten Grobogan. 2019. Kecamatan Brati dalam Angka 2019. Grobogan: Badan Pusat Statistik Kabupaten Grobogan

Dakelan, et al. 2016. Mewujudkan Desa Inklusif. Jakarta: Direktorat Jenderal Pendidikan Islam Kementrian Agama Republik Indonesia

Kementrian Desa, Pembangunan Daerah Tertinggal dan Transmigrasi. (2016). Pokok-Pokok Kebijakan Prioritas Penggunaan Dana Desa Tahun 2016. Jakarta: Dirjen Pembangunan dan Pemberdayaan Masyarakat Desa.

Mardikanto, Totok dan Poerwoko Soebiato. 2013. Pemberdayaan Masyarakat dalam Perspektif Kebijakan Publik. Bandung: Penerbit Alfabeta 
Peraturan Menteri Dalam Negeri Nomor 37 Tahun 2007 Tentang Pedoman Umum Tata Cara Pelaporan dan Pertanggungjawaban

Penyelenggaraan Pemerintahan Desa

Peraturan Menteri Dalam Negeri Nomor 114 Tahun 2014 tentang Pedoman Pembangunan Desa

Sutoro, E, et al. 2014. Desa Membangun Indonesia. Yogyakarta: Forum
Pengembangan Pembaharuan Desa

Undang-undang Nomor 6 Tahun 2014 tentang Desa

Wahidi, R. 2015. Membangun Perdesaan Modern. Bogor: Indec

Waskitoaji, Damar, et al. 2016. Model Proses Pengangaran

Pembangunan Desa secara Partisipatif. Salatiga: Lembaga Percik 